\title{
Profil Kematian Neonatus di RSUD dr. Soetomo
}

\author{
Shanty Djajakusli, Agus Harianto, Risa Etika, Martono TU, Budiono \\ Bagian Ilmu Kesehatan Anak Fakultas Kedokteran Universitas Airlangga, Surabaya
}

Latar belakang. Upaya menurunkan angka kematian neonatus belum optimal sesuai dengan yang ditargetkan MDG's 2015, yaitu menurunkan angka kematian neonatus menjadi 23/1000 kelahiran hidup.

Tujuan. Mengetahui profil kematian neonatus berdasarkan faktor maternal, faktor neonatal, sosio-demografi, keadaan klinis neonatus lahir hidup, usia $\leq 7$ hari, sampai 28 hari serta mengetahui penyebab kematian neonatus dini dan neonatus lanjut.

Metode. Penelitian deskriptif dilakukan di ruang Intensif Instalasi Rawat Darurat, Gedung Bedah Pusat Terpadu dan ruang Intermediate Neonatal SMF Ilmu Kesehatan Anak RSUD dr. Soetomo. Penelitian dimulai 1 September 2014 sampai 28 Februari 2015. Pengumpulan data menggunakan Lembar Pengumpul Data Perinasia Pusat, setiap neonatus yang dirawat kemudian meninggal dimasukkan kematian neonatus dini maupun lanjut, dicatat keadaan klinis, serta faktor risiko dari ibu dan neonatus.

Hasil. Dari 807 kelahiran neonatus didapatkan 101 (12,5\%) kematian neonatus terdiri dari 63 (7,8\%) kematian neonatus dini dan $38(4,7 \%)$ kematian neonatus lanjut. Kematian neonatus dini dan lanjut ditemukan paling banyak pada neonatus $\mathrm{BBL} \geq 2500 \mathrm{~g}$ $(34,9 \%$ dan $50 \%)$, laki-laki $(61,9 \%$ dan $71,1 \%)$, tunggal $(95,2 \%$ dan $199 \%)$ dan sesuai masa kehamilan $(79,4 \%$ dan $84,2 \%)$ serta usia ibu $20-25$ tahun $(82,5 \%$ dan $71,1 \%)$. Sesak $(95,2 \%$ dan $86,8 \%)$ dan sepsis $(66,7 \%$ dan $63,2 \%)$ merupakan keadaaan klinis neonatus pada usia $\leq 7$ hari sementara keadaan klinis kematian neonatus lanjut sampai usia 28 hari terutama sesak (100\%), sepsis $(84,2 \%)$, dan pneumonia $(52,6 \%)$.

Kesimpulan. Profil penyebab kematian neonatus yang sering ditemukan adalah sepsis, prematuritas, asfiksia, dan kelainan bawaan. Sari Pediatri 2017;18(6):474-80

Kata kunci: faktor risiko, kematian neonatus

\section{Profile of Neonatal Mortality at RSUD dr. Soetomo}

Shanty Djajakusli, Agus Harianto, Risa Etika, Martono TU, Budiono

Departement of Child Health Medical School Airlangga University, Surabaya

Background. Efforts to reduce neonatal mortality has not been optimal as targeted by MDG's 2015, which reduces the number of neonatal deaths to $23 / 1000$ live births.

Objective. To identify the profile of neonatal deaths based on data of maternal and socio-demographic characteristics of neonatal, maternal, clinical state of neonates born alive, aged $\leq 7$ days and up to 28 days as well as cause of death early and late neonates.

Method. Descriptive research was conducted in the Intensive Emergency Installation Installation Room, Central Integrated Surgical Center and Intermediate Neonatal Room SMF Child Health Sciences RSUD dr. Soetomo. The study began September 1, 2014 to February 28, 2015. Data collection using the Central Perinase Data Collection Sheet, each neonate treated subsequently died including neonatal and neonatal deaths later, recorded clinical circumstances, as well as maternal and neonatal risk factors.

Results. Of the 807 neonatal births, $101(12.5 \%)$ of neonatal deaths were found to be $63(7.8 \%)$ of early neonatal death and 38 $(4.7 \%)$ of advanced neonatal deaths. Early and advanced neonatal deaths were found to be highest in neonate $\mathrm{BBL} \geq 2500 \mathrm{~g}(34.9 \%$ and $50 \%)$, men $(61.9 \%$ and $71.1 \%)$, single (95.2\% and $199 \%)$ and According to gestation (79.4\% and $84.2 \%)$ and maternal age $20-25$ years $(82.5 \%$ and $71.1 \%)$. Shortness $(95.2 \%$ and $86.8 \%)$ and sepsis $(66.7 \%$ and $63.2 \%)$ were clinical neonates at age $\leq 7$ days while clinical neonatal death to 28 days was mainly congested (100\%), Sepsis (84.2\%) and pneumonia (52.6\%).

Conclusion. Common neonatal death profiles are sepsis, premature, asphyxia, and congenital abnormalities. Sari Pediatri 2017; 18(6):474-80

Keywords: risk factors, neonatal death

Alamat korespondensi: Dr., Shanty Djajakusli SpA(K). Departemen Ilmu Kesehatan Anak Fakultas Kedokteran UNAIR, Divisi Neonatologi, Surabaya. Telpon: 085242636933. Email: Sh4ntydjajakusli@yahoo.com 
B erdasarkan data World Health Organization (WHO), jumlah kematian neonatus menurun dari 4,4 juta pada tahun 1990 menjadi 3 juta pada tahun 2011. Angka kematian neonatus menurun dari 32/1000 kelahiran hidup menjadi 22/1000 kelahiran hidup pada periode yang sama, mengalami penurunan lebih dari 30\%. Penurunan ini lebih lambat dibandingkan kematian anak secara keseluruhan. Prematuritas adalah penyebab utama kematian neonatus dan saat ini merupakan penyebab utama kematian pada anak dibawah usia lima tahun. ${ }^{1}$ Lebih dari satu juta bayi prematur meninggal sesaat setelah lahir. Indonesia menduduki peringkat ke-5 jumlah bayi prematur terbanyak di dunia dengan jumlah $675.700 .^{2}$ Angka kematian neonatus di Indonesia pada tahun 2002 dilaporkan 20 per 1000 kelahiran hidup, yang menurut WHO mirip dengan rata-rata untuk negara-negara Asia Tenggara lainnya (19 per 1.000 kelahiran hidup). Sementara menurut Survei Demografi Kesehatan Indonesia (SDKI) 2012, angka kematian bayi (AKB) 32/1000 kelahiran hidup. ${ }^{3,4}$

Laporan Dinas Kesehatan Provinsi Jatim pada tahun 2008 tercatat 4368 bayi meninggal dari 558.934 kelahiran. Sementara menurut estimasi BPS, AKB di Provinsi Jawa Timur 32,2, 31,41/1000, 29,99/1000, 29,24/1000 pada tahun 2008, 2009, 2010, 2011. Walaupun menunjukkan tren menurun selama 4 tahun terakhir, AKB tersebut masih jauh dari target nasional 2010 yang diproyeksikan sebesar 25,7 per 1000 kelahiran hidup, sedangkan target MDG's 2015 nomor 4 menurunkan AKB dari 35 menjadi 23/1000 kelahiran hidup. ${ }^{5-8}$

Penyebab utama kematian neonatal pada minggu pertama (0-6 hari) adalah asfiksia (36\%), BBLR/ prematuritas (32\%), serta sepsis (12\%). Sementara penyebab kematian neonatus (7-28 hari) adalah sepsis (22\%), kelainan kongenital (18\%), dan pneumonia (17\%). 3,5,6 Di rumah sakit dr. Soetomo, jumlah kematian tahun 2014235 (12,1\%) dengan penyebab yang tersering adalah RDS, sepsis, BBLASR, asfiksia, pneumonia, gagal jantung, MAS, PPHN, TEF, dan HIE.

Titaley $\mathrm{dkk}^{4}$ menganalisis data Demografi dan Kesehatan Indonesia dengan jumlah sampel 15.952 bayi tunggal lahir hidup antara tahun 1997-2002 dan menemukan bahwa kematian bayi di Jawa Timur lebih tinggi, terutama bayi yang lahir dari kedua orang tua bekerja, jenis kelamin laki-laki, prematur/ BBLR, bayi dari ibu dengan riwayat komplikasi persalinan. Sementara menurut Pramono dkk, ${ }^{6}$ angka kematian bayi di Jawa Timur tahun 2007 adalah sebesar 32,93 yang berarti ada sekitar 33 kematian bayi setiap 1000 kelahiran hidup.

Di Indonesia, terutama RSUD dr. Soetomo, belum pernah dilakukan pengumpulan data dengan menggunakan Lembar Pengumpul Data Perinasia Pusat. Peneliti melakukan penelitian pengumpulan data untuk mengetahui jumlah kematian neonatus, profil risiko, dan penyebab kematian neonatus pada bayi yang dirawat di bagian neonatologi RSUD Dr. Soetomo Surabaya. Dengan mengetahui profil kematian neonatus diharapkan dapat membantu dalam penanganan, pemberian terapi dan pencegahan sehingga dapat mengurangi jumlah kematian neonatus.

\section{Metode}

Penelitian dilakukan pada neonatus yang dirawat dan meninggal di ruang Intensif Instalasi Rawat Darurat, Gedung Bedah Pusat Terpadu dan ruang Intermediate Neonatal SMF Ilmu Kesehatan Anak RSUD dr. Soetomo mulai 1 September 2014 sampai 28 Februari 2015. Pengumpulan data digunakan Lembar Pengumpul Data Perinasia Pusat dengan pengambilan sampel secara consecutive sampling dan perkiraan besar sampel 31 neonatus yang meninggal. Data diidentifikasi ke dalam kelompok kematian neonatus dini dan lanjut termasuk faktor risiko dari ibu dan neonatus dan dianalisis secara deskriptif. Kriteria inklusi adalah umur pasien $\leq 28$ hari dan dinyatakan meninggal oleh dokter. Kriteria eksklusi adalah pasien yang meninggal di luar dari ketiga tempat yang telah ditentukan meskipun dalam lingkungan RSUD Dr. Soetomo dan pasien pulang paksa.

\section{Hasil}

Didapatkan 101 (12,5\%) kematian neonatus dari 807 kelahiran neonatus baik yang terdiri dari $63(7,8 \%)$ kematian neonatus dini dan 38 (4,7\%) kematian neonatus lanjut. Karakteristik sampel dari penelitian ini tertera pada Tabel 1 .

Pada Tabel 1 tertera karakteristik pasien yang dirawat lebih banyak laki-laki, prematur, SMK, bayi 
Tabel 1. Karakteristik subyek penelitian

\begin{tabular}{|c|c|c|}
\hline Variabel & $\mathrm{N}$ & $(\%)$ \\
\hline \multicolumn{3}{|l|}{ Jenis kelamin } \\
\hline Laki-laki & 66 & 65,3 \\
\hline Perempuan & 35 & 34,7 \\
\hline \multicolumn{3}{|l|}{ Bayi berat lahir (gram) } \\
\hline$<1000$ & 9 & 8,9 \\
\hline $1000-<1500$ & 22 & 21,8 \\
\hline $1500-<2500$ & 29 & 28,7 \\
\hline$\geq 2500$ & 41 & 40,6 \\
\hline \multicolumn{3}{|l|}{ Pertumbuhan janin } \\
\hline SMK & 82 & 81,2 \\
\hline KMK & 18 & 17,8 \\
\hline BMK & 1 & 1 \\
\hline \multicolumn{3}{|l|}{ Usia gestasi } \\
\hline Prematur & 56 & 55,4 \\
\hline Aterm & 45 & 44,6 \\
\hline Postdate & 0 & 0 \\
\hline \multicolumn{3}{|l|}{ Lahir } \\
\hline Tunggal & 98 & 97 \\
\hline Kembar & 3 & 3 \\
\hline \multicolumn{3}{|l|}{ Umur ibu (tahun) } \\
\hline$<20$ & 6 & 5,9 \\
\hline $20-35$ & 79 & 78,2 \\
\hline$>35$ & 16 & 15,8 \\
\hline \multicolumn{3}{|c|}{ Nilai Apgar 1 menit pertama } \\
\hline $1-3$ & 40 & 46 \\
\hline $4-6$ & 29 & 33,3 \\
\hline $7-9$ & 18 & 20,7 \\
\hline \multicolumn{3}{|c|}{ Nilai Apgar 5 menit pertama } \\
\hline $1-3$ & 22 & 25,3 \\
\hline $4-6$ & 23 & 26,4 \\
\hline $7-9$ & 42 & 48,3 \\
\hline \multicolumn{3}{|l|}{ Tempat lahir } \\
\hline RSUD Dr. Soetomo & 51 & 50,5 \\
\hline RS lain & 35 & 34,7 \\
\hline Bidan & 10 & 9,9 \\
\hline Lainnya & 5 & 5 \\
\hline \multicolumn{3}{|l|}{ Cara persalinan } \\
\hline Sectio caesarea & 56 & 55,4 \\
\hline Spontan & 45 & 44,6 \\
\hline \multicolumn{3}{|l|}{ Presentasi persalinan } \\
\hline Belakang kepala & 90 & 89,1 \\
\hline Puncak & 1 & 1 \\
\hline Sungsang & 4 & 4 \\
\hline Lintang & 3 & 3 \\
\hline Bokong & 3 & 3 \\
\hline
\end{tabular}




\begin{tabular}{lcc}
\hline Variabel & $\mathrm{N}$ & $(\%)$ \\
\hline Kelainan bawaan & & \\
Gastrointestinal (atresia ileum, gastroschisis, laringomalacia, omfalokel, esofageal, CLP, & 17 & 30,9 \\
HPS, ductus omphaloentericus, MAR) & 13 & 23,6 \\
CHD & 9 & 16,4 \\
Multiple congenital \& sindrom (DS, Harlequin ichtiosis, DSD) & & \\
Neuromuskular (meningocele, anensefali, makrosefal, spina bifida) & 6 & 10,9 \\
Ekstremitas (CTEV, polidaktili) & 5 & 9,1 \\
Neuromuskular & 4 & 7,3 \\
Genitalia (UDT, hipospadia, mikropenis) & 1 & 1,8 \\
Kelainan mata & 4 & 0,5 \\
Trauma lahir
\end{tabular}

Tabel 2. Perbandingan keadaan klinis bayi saat lahir

\begin{tabular}{lcccc}
\hline Variabel & $\begin{array}{c}\text { Kematian neonatal } \\
\text { Dini, } \mathrm{n}(\%)\end{array}$ & $\begin{array}{c}\text { Kematian neonatal } \\
\text { Lanjut, } \mathrm{n}(\%)\end{array}$ & $\mathrm{N}$ & $(\%)$ \\
\hline Resusitasi & $36(58,1)$ & $10(26,3)$ & 46 & 46 \\
Asfiksia & $39(61,9)$ & $10(26,3)$ & 49 & 48,5 \\
Nilai Apgar 1 menit pertama & & & & \\
$\quad(1-3)$ & $32(54,2)$ & $8(28,6)$ & 40 & 46 \\
$(4-6)$ & $16(27,1)$ & $13(46,4)$ & 29 & 33,3 \\
$\quad(7-9)$ & $11(18,6)$ & $7(25,0)$ & 18 & 20,7 \\
Nilai Apgar 5 menit pertama & & & & \\
$\quad(1-3)$ & $18(30,5)$ & $4(14,3)$ & 22 & 25,3 \\
$(4-6)$ & $18(30,5)$ & $5(17,9)$ & 23 & 26,4 \\
$(7-9)$ & $23(39,0)$ & $19(67,9)$ & 42 & 48,3 \\
\hline
\end{tabular}

berat lahir $\geq 2500 \mathrm{~g}$, lahir tunggal, usia ibu 20-35 tahun, nilai Apgar 1 menit pertama 1-3, persalinan dengan operasi sectio caesarea dan letak belakang kepala. Neonatus yang dirawat kebanyakan lahir di di RSUD dr. Soetomo. Kelainan bawaan cukup banyak dan yang tersering neonatus dengan kelainan gastrointestinal dan congenital heart disease. Pada kasus neonatus yang dirawat jarang dengan trauma saat lahir.

Tabel 2 memperlihatkan bahwa kematian neonatus dini lebih banyak lahir mendapat resusitasi dengan riwayat asfiksia dan nilai Apgar 1 menit pertama berat (1-3).

Sesak/distres napas 60 (95,2\%), sepsis $42(66,7 \%)$ dan RDS 13 (20,6\%) merupakan keadaan klinis yang paling sering ditemukan pada bayi sampai usia $\leq 7$ hari terutama yang termasuk dalam kematian neonatus dini. Sementara keadaan klinis bayi sampai dengan usia 28 hari atau usia cukup bulan yang paling sering ditemukan adalah sesak 38 (100\%), sepsis $32(84,2 \%)$ dan pneumonia $20(52,6 \%)$, terutama pada kematian neonatus lanjut.

Masalah medis dari ibu yang ditemukan paling sering adalah hipertensi $(19,8 \%)$, obesitas (5\%), penyakit jantung (4\%), hepatitis B (4\%), DM (3\%), dan SLE (2\%). Ibu dengan masalah medis tersebut, lebih cenderung melahirkan neonatus yang termasuk dalam kematian neonatus dini.

Masalah obstetri dan komplikasi persalinan yang sering ditemukan pada ibu adalah pre eklampsi berat (PEB) (12,9\%), ketuban pecah prematur (KPP) (7,9\%), eklampsi, dan sindrom hemolysis elevated liver enzymes low platelets (HELLP) (5,9\%), dan anemia berat $(4 \%)$, terutama neonatus yang termasuk dalam kematian neonatus dini. Sementara ketuban mekoneal (5\%) ditemukan pada neonatus yang termasuk dalam kematian neonatus lanjut.

Sepsis dan gagal napas merupakan penyakit/ keadaan yang paling sering ditemukan pada kematian neonatus baik neonatus dini maupun lanjut. Selain itu faktor kelainan jantung, kelainan bawaan, gagal 
Shanty Djajakusli dkk: Profil kematian neonatus

Tabel 3. Penyakit/keadaan yang ditemukan pada kematian neonatus dini dan neonatus lanjut

\begin{tabular}{lcccc}
\hline Variabel & $\begin{array}{c}\text { Kematian neonatal } \\
\text { dini, }(\%)\end{array}$ & $\begin{array}{c}\text { Kematian neonatal } \\
\text { lanjut, } \mathrm{n}(\%)\end{array}$ & $\mathrm{N}$ & $(\%)$ \\
\hline Gagal napas & $42(66,7)$ & $37(97,4)$ & 79 & 78,2 \\
Sepsis & $28(44,4)$ & $26(68,4)$ & 54 & 53,5 \\
Gagal jantung & $10(15,9)$ & $14(36,8)$ & 24 & 23,8 \\
Kelainan bawaan & $12(19)$ & $12(31,6)$ & 24 & 23,8 \\
Kelainan jantung & $3(4,8)$ & $14(36,8)$ & 17 & 16,8 \\
Pneumonia & $1(1,6)$ & $13(34,2)$ & 14 & 13,9 \\
RDS & $10(15,9)$ & $1(2,6)$ & 11 & 10,9 \\
NEC & $2(3,2)$ & $4(10,5)$ & 6 & 5,9 \\
MAS & $3(4,8)$ & $2(5,3)$ & 5 & 5 \\
PPHN & $2(3,2)$ & $3(7,9)$ & 5 & 5 \\
Perdarahan & $2(3,2)$ & $2(5,3)$ & 4 & 4 \\
Pulmonal hemorrhage & $2(3,2)$ & $2(5,3)$ & 4 & 4 \\
Proses sentral & $2(3,2)$ & $2(5,3)$ & 4 & 4 \\
Pneumo-toraks & $2(3,2)$ & $1(2,6)$ & 3 & 3 \\
Hepatitis & $1(1,6)$ & $2(5,3)$ & 3 & 3 \\
\hline
\end{tabular}

MAS: meconium aspiration syndrome, PPHN: persistent pulmonal hypertension of the newborn, RDS: respiratory distress syndrome, NEC: necrotizing enterocolitis

jantung, RDS, dan MAS cukup sering mempengaruhi kematian neonatus.

\section{Pembahasan}

Penelitian ini didasari dari suatu lembar pengumpulan data yang dikeluarkan oleh Perinasia Pusat tentang formulir kematian neonatus dan lahir mati yang akan dilakukan multisenter di Indonesia. Faktor-faktor yang mempengaruhi kematian neonatus dapat dari faktor ibu maupun dari neonatus. Peneliti ingin melihat profil kematian neonatus selama 6 bulan terutama yang dirawat di RSUD dr. Soetomo, Surabaya.

Selama periode penelitian didapatkan 101 kematian neonatus dari 807 kelahiran neonatus, baik yang lahir di RSUD dr. Soetomo (50,5\%) maupun lahir di rumah sakit lain $(34,7 \%)$, bidan praktek swasta $(9,9 \%)$, rumah atau tempat lain $(5 \%)$. Jenis kelamin laki-laki $(65,3 \%)$ lebih banyak meninggal dibanding perempuan $(34,7 \%)$. Jenis kelamin laki-laki merupakan salah satu faktor risiko pada beberapa penyakit, antara lain, RDS, bronchopulmonary dysplasialchronic lung disease (BPD/CLD), serta sepsis neonatorum yang harus dipertimbangkan. Pada kasus sepsis, faktor risiko lakilaki memiliki 4x lebih besar terpengaruh dibandingkan perempuan dan kemungkinan berdasarkan gen yang terkait jenis kelamin. ${ }^{10}$

Kami menemukan kematian neonatus pada bayi prematur $(55,4 \%)$ dan berat lahir $<2500$ gram $(59,4 \%)$, tetapi kematian neonatus pada bayi dengan berat lahir $\geq 2500 \mathrm{~g}(40,6 \%)$ cukup banyak, sebagian besar disertai dengan kelainan kongenital $(68,3 \%)$ dan merupakan rujukan dari luar RSUD dr. Soetomo (80,4\%). Panjvani $\mathrm{dkk}^{11}$ melaporkan bahwa penyebab kematian bayi dengan berat $\geq 2500$ g yang dilakukan di rumah sakit City Inner selama lebih dari satu periode 18 tahun adalah kelainan kongenital. Demikian pula menurut Gomella ${ }^{12}$ bahwa neonatus yang menderita kelainan bawaan memiliki rawat inap yang lebih lama dan meningkatkan angka kematian. Malformasi dapat menyebabkan $>20 \%$ kematian neonatus.

Kematian neonatus dini lebih banyak yang mengalami asfiksia, terlihat dari nilai Apgar 1 menit pertama $\leq 3$ sehingga memerlukan resusitasi. Meskipun nilai Apgar pada kematian neonatus lanjut lebih tinggi, faktor lain ikut memengaruhi kematian neonatus, baik dari ibu maupun dari neonatus. Yego $\mathrm{dkk}^{13}$ melaporkan bahwa penyebab kematian neonatus dini adalah ketuban pecah dini, prematur dan asfiksia.

Kasus asfiksia neonatorum cukup tinggi (48,5\%). Menurut WHO, asfiksia neonatorum merupakan 
persentase terbesar kedua penyebab kematian neonatus. Untuk menurunkan angka kematian neonatus, kunci utama terletak pada kualitas perawatan neonatus emergensi. Diperkirakan sepertiga bayi yang membutuhkan resusitasi tidak memperlihatkan tanda bahaya. Oleh sebab itu, hal ini sangat kritis bagi petugas kesehatan dilengkapi dan dilatih untuk dapat melakukan resusitasi neonatus yang sederhana dan efektif pada setiap persalinan. Dari hasil SKRT 2001, kematian neonatus akibat asfiksia saat lahir menduduki urutan ke dua sebesar $27 \% .^{14}$

Masalah medis ibu yang paling sering ditemukan pada adalah hipertensi, penyakit jantung, diabetes mellitus (DM), obesitas, dan hepatitis B yang ratarata dapat menyebabkan komplikasi pada janin. Berdasarkan teori bahwa ibu dengan penyakit mikrovaskular lanjut seperti hipertensi, retinopati, dan nefropati berisiko $25 \%$ melahirkan prematur karena memburuknya kondisi ibu atau preeklampsi. ${ }^{15}$

Kehamilan tidak berdampak signifikan terhadap perkembangan diabetes. Ibu yang memulai kehamilan dengan penyakit mikrovaskular, diabetes sering memburuk, tetapi dalam banyak kasus, penyakit kembali membaik. Kontrol glukosa prakonsepsi dapat mengurangi tingkat komplikasi ke level yang terlihat pada populasi umum. ${ }^{15}$

Diabetes yang mendahului kehamilan dapat dihubungkan dengan hasil janin dan ibu yang merugikan. Komplikasi yang paling penting adalah embriopati diabetes yang mengakibatkan kelainan kongenital. Kelainan kongenital terkait dengan $50 \%$ kematian perinatal pada ibu dengan diabetes dibandingkan dengan $25 \%$ di antara ibu tanpa DM. Risiko kelainan kongenital yang dihubungkan dengan profil glikemik pada saat pembuahan. Ibu dengan DM tipe 1 dan tipe 2 meningkatkan risiko gangguan hipertensi, seperti preeklampsi, yang berpotensi merusak hubungan antara ibu dan janin. Gestational diabetes mellitus (GDM) didefinisikan sebagai variabel intoleransi karbohidrat yang berat yang pertama didiagnosis selama kehamilan, dan hal ini memengaruhi 3\%-5\% dari kehamilan. ${ }^{15}$

Ketuban pecah prematur, PEB, eklampsi, dan sindrom HELLP merupakan masalah obstetri dan komplikasi persalinan yang sering ditemukan pada ibu, terutama kematian neonatus dini. Selain itu, komplikasi persalinan pada neonatus yang termasuk kematian neonatus lanjut adalah ketuban mekoneal. Komplikasi preeklampsia menghasilkan angka kematian ibu dari 3 per 100.000 kelahiran hidup di Amerika Serikat. Morbiditas ibu termasuk komplikasi sistem saraf pusat (misalnya kejang, perdarahan intraserebral, dan kebutaan), KID, gagal hati, edema paru, dan solusio plasenta menyebabkan perdarahan ibu dan/ atau gagal ginjal akut. Kematian janin meningkat dengan peningkatan tekanan darah diastolik ibu dan proteinuria. Tekanan darah diastolik $>95 \mathrm{~mm} \mathrm{Hg}$ berhubungan dengan kenaikan tiga kali lipat angka kematian janin. Morbiditas janin termasuk intrauterine growth retardation (IUGR), asidemia janin, dan komplikasi dari prematuritas. ${ }^{16}$

Ketuban mekoneal merupakan komplikasi yang memengaruhi kematian neonatus. Martono ${ }^{17}$ melaporkan bahwa bahwa ketuban mekoneal merupakan faktor risiko yang signifikan meningkatkan risiko sepsis 2,5 $\mathrm{x}$ dibandingkan tanpa mekoneal pada air ketuban.

Dalam penelitian kami, gagal jantung, gagal napas, PPHN, sepsis, perdarahan, NEC, RDS, MAS, pneumotoraks, perdarahan paru, pneumonia, kelainan jantung, kelainan bawaan, hepatitis dan proses sentral merupakan penyakit/keadaan yang sering ditemukan pada kematian neonatus. Namun, sepsis dan gagal napas merupakan penyakit/keadaan yang lebih sering ditemukan pada kematian neonatus, baik pada kematian neonatus dini maupun neonatus lanjut.

Salah satu risiko kematian karena prematuritas atau penyebab lain yang terjadi setelah minggu pertama kehidupan sebagai penyebab kematian oleh sepsis adalah penggunaan instrumen. Hasil penelitian kami serupa dengan penelitian lain yang memperlihatkan kondisi bayi prematur yang relatif imunodefisiensi dan mendapat beberapa prosedur invasif dan perlu pengawasan terhadap infeksi nosokomial karena dapat menjadi sepsis. ${ }^{17,18}$

Penelitian yang dilakukan Oza dkk ${ }^{19}$ memperlihatkan bahwa baik periode dini dan lanjut, kelahiran prematur dan komplikasi intrapartum serta infeksi memberi andil yang besar dalam kematian neonatus.

Keterbatasan dalam penelitian kami, antara lain, tidak terdapat kelompok kontrol, bayi yang lahir mati belum dilibatkan dalam penelitian, dan tidak menganalisis faktor yang memengaruhi kematian neonatus maupun hubungan antara masing-masing faktor.

Disimpulkan bahwa profil kematian neonatus yang sering ditemukan adalah sepsis, prematur, asfiksia, dan kelainan bawaan. 


\section{Daftar pustaka}

1. WHO. Preterm birth. Fact sheet. Mediacentre 2016:1-5.

2. Wahyuningsih $\mathrm{M}$. Indonesia urutan ke-5 terbanyak lahirkan bayi prematur, India no.1. Diakses pada 5 April 2017. Didapat dari: https://health.detik.com/read/2012/05/12/120159/191 5559/1300/indonesia-urutan-ke-5-terbanyak-lahirkan-bayiprematur-india-no-1

3. Risa E. Tatalaksana kegawatdaruratan neonatus. Surabaya: Dinas Kesehatan Kabupaten Lumajang; 2015.

4. Titaley CR, Dibley MJ, Agho K, Roberts CL, Hall J. Determinants of neonatal mortality in Indonesia. BMC Public Health 2008;8:232-43.

5. Harianto A. Peran dokter umum dalam penanganan dini kegawatdaruratan bayi baru lahir. Surabaya: Perdudikes Jawa Timur; 2013.

6. Pramono MS, Wulansari S, Sutikno. Pemetaan determinan angka kematian bayi di Jawa Timur berdasarkan indikator indeks pembangunan kesehatan masyarakat. Buletin Penelitian Sistem Kesehatan 2012; 15:38-46.

7. PPID Dinas Komunikasi dan Informatika Pemerintah Provinsi Jawa Timur. Turun, angka kematian bayi di Jatim. Kominfo; Surabaya, Kominfo Jawa Timur; 2011.

8. Risa E, Agus H, Martono TU, Dina A, Kartika DH, Mahendra TAS. Infection in neonates and infants : Epidemiology aspects. Surabaya: Pediatric Infectious Diseases Weekend; 2014.

9. Data NICU Staf neonatologi. Laporan tahunan NICU IRD RSUD dr. Soetomo. Surabaya; 2014.

10. Smith VC. Identifying the high risk newborn, anticipation, evaluation, management and outcome. Dalam: Cloherty JP, Eichenwald EC, Hansen AR, Stark AR, penyunting. Manual of neonatal care. Edisi ke-7. Philadelphia: Lippincott William \& Wilkins; 2012.h.74-90.

11. Panjvani Z, Torres E, Castillo R, Benamanahalli K, Rajegowda
M. Mortality Trends and Cause of Death Among Infants Weighing $2.5 \mathrm{~kg}$ or More at Birth in an Inner City Hospital Over an 18 Year Period. J Neonatol Res 2012; 2:190-4.

12. Mohammed FMB. Sepsis. Dalam : Gomella TL, Cunningham MD, Eyal FG, Tuttle, penyunting. Neonatology: management, procedures, on call problems, diseases and drug. Edisi ke-6. New York: McGraw Hill; 2009.h.665-72.

13. Yego F, Williams JS, Byles J, Nyongesa P, Aruasa W, D'Este C. A retrospective analysis of maternal and neonatal mortality at a teaching and referral hospital in Kenya. Reproductive Health 2013;10:13:1-8.

14. Djaja S, Soemantri S. Penyebab kematian bayi baru lahir (neonatal) dan sistem pelayanan kesehatan yang berkaitan di Indonesia Survei kesehatan rumah tangga (SKRT). Puslitbang Ekologi Kesehatan Badan Penelitian Kesehatan 2003;31:155-65.

15. Parritz AL, Cloherty JP. Diabetes mellitus. Dalam: Cloherty JP, Eichenwald EC, Hansen AR, Stark AR, penyunting. Manual of neonatal care. Edisi ke-7. Philadelphia: Lippincott William \& Wilkins; 2012.h.11-23.

16. McElrath TF. Preeclampsia and related conditions. Dalam: Cloherty JP, Eichenwald EC, Hansen AR, Stark AR, penyunting. Manual of neonatal care. Edisi ke-7. Philadelphia: Lippincott William \& Wilkins; 2012.h.39-46.

17. Martono TU. Risk factors of neonatal sepsis : A preliminary study in dr. Soetomo Hospital. Indones J Trop Infect Dis 2010;1:23-6.

18. Sankar MJ, Natarajan CK, Das RR, Agarwal R, chandrasekaran A, Paul VK. When do newborns die? A systematic review of timing of overall and cause-specific neonatal deaths in developing countries. J Perinatol 2016;36:S1-11.

19. Oza S, Lawn JE, Hogan DR, Mathers C, Cousens SN. Neonatal cause-of-death estimates for the early and late neonatal periods for 194 countries: 2000-2013. Bulletin of the World Health Organization 2015;93:19-28. 